\title{
A rare and dangerous infectious lesion: Hydatid disease of the cervical spine
}

\author{
Nadir ve tehlikeli bir enfeksiyöz lezyon: Servikal hidatik kist \\ Kevser Özdemir ${ }^{1}$, Mustafa Korucu², Muhammet ibrahimoğlu², Cihan Kaya ${ }^{3}$, Mevci Özdemir² ${ }^{2}$ Bayram Çırak ${ }^{2}$
}

\begin{abstract}
Hydatidosis is an infectious disease caused mostly by Echinococcus granulosus. A 63-year-old male was admitted to our institute with the complaints of tetraparesis. Magnetic resonans imaging revealed a multilobular, cystic lesion in the cervical epidural region. Using posterior cervical approach, total cyst excision was performed. Histopathological examination revealed as a hydatid cyst. Cervical spinal hydatid cyst is an extremely rare pathology. The goal of surgery is to remove all the cysts without rupture in the early course of the disease. Surgical area should be washed with saline solution and albendazole is the first line drug in the treatment. J Clin Exp Invest 2014; 5 (3): 452-455
\end{abstract}

Key words: Echinococcus granulosus, infection, spinal cyst, albendazole

\section{INTRODUCTION}

Hydatid cyst is a parasitic disease and it is especially seen in countries where animal husbandries are common. Pathogen of the disease belonging to the class Cestoda is Echinococcus. Echinococcus granulosus is the most common type of pathogens and it leads the disease by forming a pouch. The number of cysts may be one or more. According to localizations of the cyst, we see different symptoms and findings [1]. \%75 of hydatid cyst cases affects liver and \%10-15 of them affects lung. Bone involvement is seen in only $0.5-2 \%$ of cases and spine involvement is half of bone involvement [2,3]. $\% 50$ of spinal hydatid cysts are thoracal, \%30 are lomber and \%10 are cervical. The spinal form was first described by Churrier in 1807, and the first surgery was performed by Reydellet in 1819 [4]. To see cysts on the spine and around it without a cyst primer in liver or lungs is an extremely rare situa-

\section{ÖZET}

Hidatizozis sıklıkla Echinococcus granulosus'un neden olduğu enfeksiyöz bir hastalıktır. 63 yaşında erkek hasta el ve ayaklarda kuvvetsizlik şikayeti ile polikliniğimize başvurdu. Magnetik rezonans görüntülemede servikal epidural bölgede kistik multilobüler lezyon tespit edildi. Posterior yaklaşımla kist eksizyonu yapıldı. Histopatolojik inceleme sonucu hidatik kist olarak değerlendirildi. Servikal spinal hidatik kist oldukça nadir görülen bir patolojidir. Cerrahinin amacı hastalığın erken döneminde kisti rüptüre etmeden çıkarmaktır. Cerrahi alan hipertonik salin ile yıkanmalıdır ve albendazol tedavide ilk tercih edilecek ilaçtır.

Anahtar kelimeler: Echinococcus granulosus, enfeksiyon, spinal kist, servikal, albendazol

tion and it is very difficult to understand thid condition. Especially cervical site involvement is rare. We aimed to present a very rare, primary spinal hydatid cyst case in this review.

\section{CASE REPORT}

A 63 years old, male patient admitted to our clinic with neck pain and sudden onset tetraparesis that started 5 days ago. In his neurologic examination muscle strength was paretic for all extremities, Hoffman and Babinski tests were positive. In his cervical MRI, there were many non-contrast enhancing, cystic lesions at the level posterior part of C5-6 vertebra and the biggest cyst was at the $\mathrm{C} 5$ right pedicle, 21*12 $\mathrm{mm}$ in size, expansile, T1A hypointense, T2A hyperintense. Described cystic lesions were compressing the spinal cord at the posterolateral side (Figure 1). Axial sections of the level of C6 vertebra revealed numerous T1-hypointense, T2-

\footnotetext{
${ }^{1}$ Denizli State Hospital, Department of Infectious Diseases and Clinical Microbiology, Denizli, Turkey

2 Pamukkale University, Faculty of Medicine, Department of Neurosurgery, Denizli, Turkey

${ }^{3}$ Pamukkale University, Faculty of Medicine, Department of Radiology, Denizli, Turkey
}

Correspondence: Kevser Ozdemir,

Denizli State Hospital, Department of Infectious Diseases and Clinical Microbiology, Denizli, Turkey Email: drkevser@gmail.com Received: 04.08.2014, Accepted: 10.09.2014

Copyright (C) JCEI / Journal of Clinical and Experimental Investigations 2014, All rights reserved 
hyperintense cystic lesions located in both laminas and spinous process which do not show contrast enhancement after contrast administration and the biggest one was at the level of right-lamina, 12x7 $\mathrm{mm}$ in size and expansile, also some cysts had septa. Especially the posterolateral part of spinal cord seems pressed by the defined cystic lesions (Figure 2). The medical history of the patient shows us anterior corpectomy and cyst excision for the same lesion two years ago at another center. Preoperatively, chest X-ray, abdominal ultrasonography, abdominal and thoracic CT was performed and any other focus were not seen. Performed hemagglutination and ELISA tests for detection of hydatid disease were negative. Blood testing of liver function tests, kidney function tests, sedimentation and CRP values were within normal limits. Total laminectomy and cyst excision was performed in prone position with posterior cervical approach and then surgical area was irrigated profusely with hypertonic saline solution. Postoperatively $400 \mathrm{mg} /$ day albendazole was started. Neurologic deficit of the patient was completely recovered in the postoperative first month. At the patient's postoperative MR imaging taken at 3 months after surgery, absence of cysts in the epidural space and relaxation of spinal cord was observed (Figure 3).

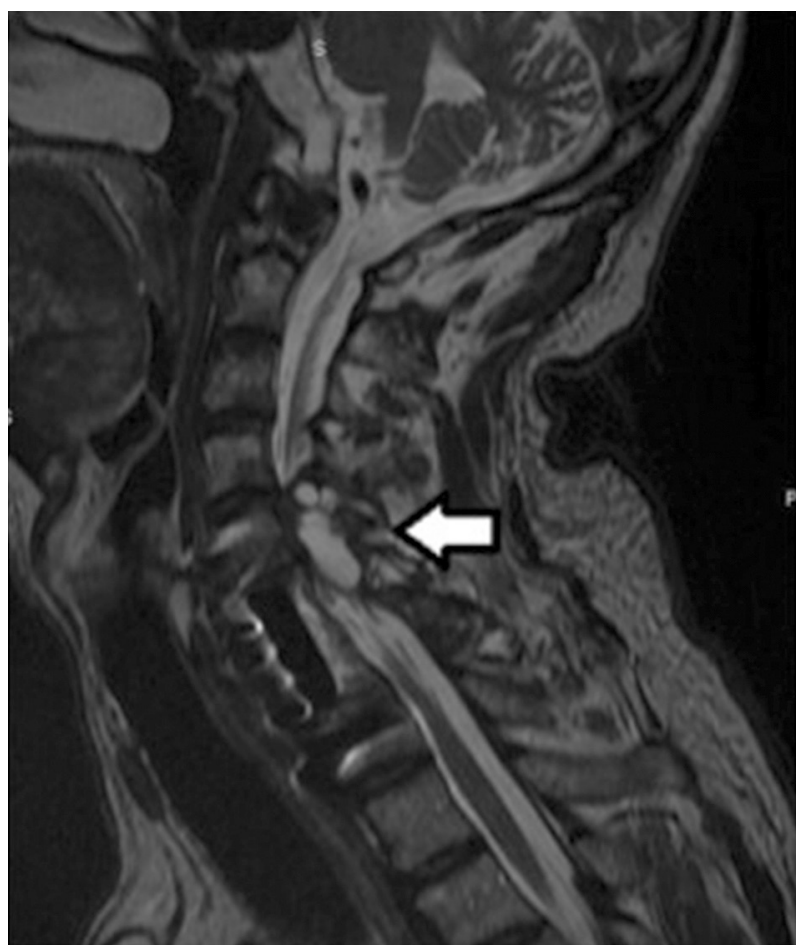

Figure 1. T2-weighted sagittal MR image. On the level of C5 and C6 vertebra, a hyperintense extradural cyst compressing to spinal cord (white arrow)

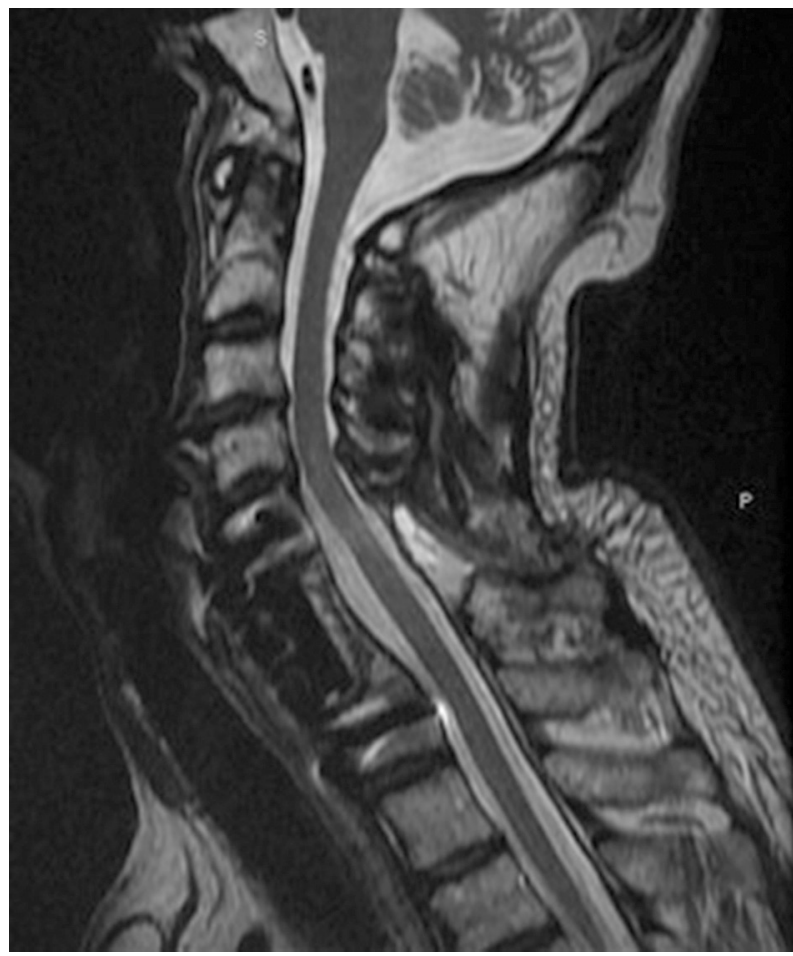

Figure 2. Axial sections of the level of C6 vertebra revealed numerous T1-hypointense, T2-hyperintense cystic lesions located in both laminas and spinous process which do not show contrast enhancement after contrast administration and the biggest one was at the level of right-lamina, 12x7 mm in size and expansile, also some cysts had septa. Especially the posterolateral parts of spinal cord seems pressed by the defined cystic lesions.

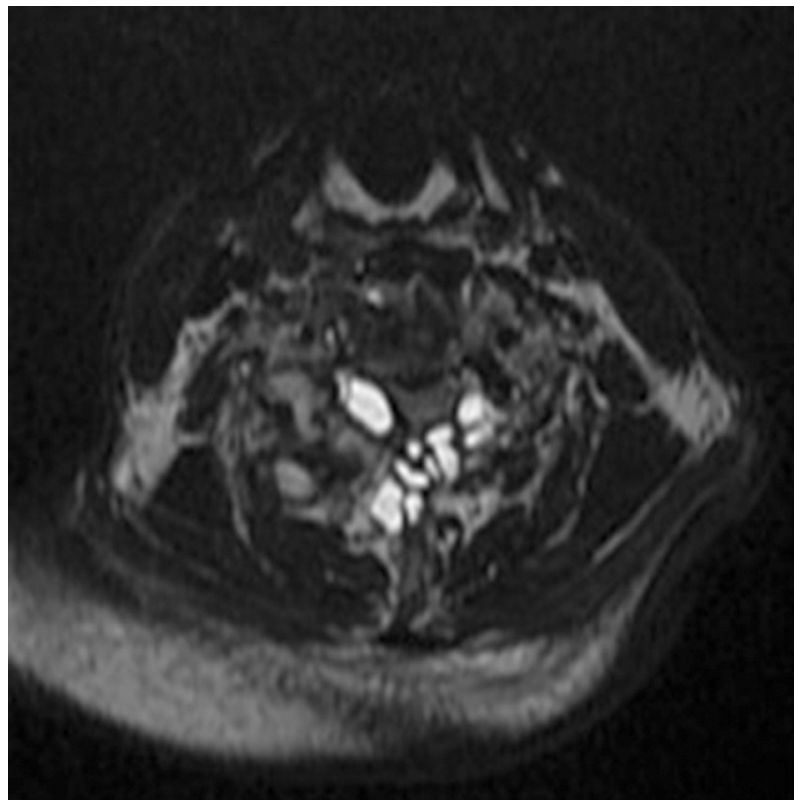

Figure 3. T2-weighted sagittal MR image. At the postoperative 3rd month, relief of spinal cord and absence of cyst in the epidural space was seen in the image. 


\section{DISCUSSION}

Hydatid disease occurs transmitting of Echinococcus granulosus eggs to natural intermediate host of sheep, goats, cattle as animals and rarely humans via water, fruits and vegetables contaminated with dog droppings. Our patient was feeding dogs for 20 years. Hydatid cyst is a quiet and difficult disease to diagnose and is going without obvious symptoms. In a meta-analysis performed in our country; in patients with spinal hydatid cyst, symptoms rates were as follows; $73 \%$ of lower extremity weakness, $43 \%$ back pain, $32 \%$ of bladder / bowel dysfunction, $27 \%$ pain in the lower extremities, $24 \%$ sensory disturbances and $2 \%$ paravertebral spasm. However, none of these symptoms alone are sufficient for diagnosis. MRI and computed tomography imagings are the best for diagnosis and follow-up. For serologic diagnosis of hydatid disease; ELISA, Western blot, indirect hemagglutination test or polymerase chain reaction tests are used [5-7]. The sensitivity of serological methods of bone involvement is low; therefore the diagnosis in suspected cases must be supported with the radiology. Bone involvement is very rare, $0.5-2 \%$ of all cases of hydatid disease shows bone involvement. Spinal involvement was detected in the $45-50 \%$ of patients with bone involvement $[8,9,10]$. $66-70 \%$ of paraplegia after spinal involvement has been reported [11]. According to Braithwaite and Lesser, spinal hydatid cysts are classified in five groups; primary intramedullary, intradural extramedullary, extradural intraspinal, vertebral and paravertebral [12]. Our case sourced primarily from the spinal area. Numerous extradural cystic lesions and cysts in the extradural, vertebral and paravertebral areas makes our case different from others. Spinal placement of hydatid cysts have been explained by the portovertebral shunt theory in the literature $[2,12,13]$. According to this theory, when intra-abdominal pressure increases, Echinococcus larvae reaches from the gastrointestinal tract to internal and external vertebral venous system before reaching the liver via retrograde flow in the vena porta using portovertebral shunts. So, it settles anywhere in the vertebrae. This site is usually corpus of the vertebrae but it can settle in lamina or pedicle of vertebrea. Intervertebral disc is not connected to the venous system, so it is not usually affected in the early period. However, even with this theory, it is still not fully understood how primary spinal hydatid disease occurs when there is no hydatid cysts in the liver [13]. Spinal cyst disease keeps the corpus first and then invades the vertebral pedicle and laminae, cystic lesions spreads to the surround- ing soft tissues after eroding the cortex [14]. Then, necrosis and calcifications occur in the bones.

MRI is the most useful diagnostic tool in spinal cyst disease [15]. It reveals the disease's spread, location and relationship with the surrounding tissue. In the differential diagnosis; Pott's disease, malignant bone tumors, perineural cysts, infections should be kept in mind. As we did in our own cases, to diagnose patient with primary spinal disorders, abdomen and thorax should be examined especially the liver and lungs. Also, it should be noted that there is no other focus. The definite diagnosis of the disease is determined by seeing intraoperatively excised cysts and histopathologic examination of them. All the cysts have to be excised for surgical treatment. However, being in locations that are difficult to reach, invasion to bone structures and spread to adjacent soft tissue make cyst excision difficult altogether. A common method applied for surgical treatment is decompressive laminectomy. Postsurgical recurrence rates ranged from $30-40 \%$. Excision without rupture of the cyst is the surgically important point. After excision, surgical area should be washed thoroughly with hypertonic saline solution. The most widely used medical treatment agent is albendazol and mebandazol. Surgical treatment and medical treatment after it, is highly effective in preventing the systemic spread of the disease and its recurrence $[16,17]$. When using the medical treatment, patients' routine liver function tests should be checked. In our case, there were spinal extradural and soft tissue involvement. There were no cyst outside the spinal area and paraspinal muscles. Spinal cord was under significant pressure, causing severe neurological deficit and bone structure was severely eroded. The patient was operated on twice before, we have operated again for the purpose of decompression due to relapse. Considering the high degree of bone erosion, we avoided radical surgery in order to avoid instability and made only excision of cysts in bone and soft areas. Then all structures were washed with hypertonic saline solution thoroughly. We have observed patient's pain improvement and the neurological benefits in the postoperative period.

As a result, without another primary focus, spinal hydatid disease is a rare disease that may lead severe to pain and serious neurological problems. In hydatid disease spine involvement is rare but cervical spine involvement alone is seen extremely rarely. Considering the invasion of the bone tissue and the high rate of relapse, radical surgery should be avoided and postoperative medical treatment 
should always be remembered. The disease can spread systemically and relapse rate is high, so patients should be checked regularly.

\section{REFERENCES}

1. Turgut M. Intracranial hydatidosis in Turkey: its clinical presentation, diagnostic studies, surgical management, and outcome. A review of 276 cases. Neurosurg Rev 2001;24:200-208.

2. Ozdemir HM, Ogün TC, Tasbas B. A lasting solution is hard to achieve in primary hydatid disease of the spine: long-term results and an overview. Spine 2004;29:932-937.

3. Pedrosa I, Saíz A, Arrazola J, et al. Hydatid disease: radiologic and pathologic features and complications. Radiographics 2000;20:795-817.

4. Caglar S, Bozkurt M, Kahilogulları G, et al. Management of a rare and dangerous Infectious lesion: Hydatid Cyst disease of the odontoid process:a case report 2012;029-032.

5. Meteroğlu F, Çalışkan A, Şahin A, et al. Atypically located hydatid cyst cases. J Clin Exp Invest 2013;4:352-355.

6. King $\mathrm{CH}$, Fairley JK. Cestodes. In: Mandell GL, editors. Mandell, Douglas and Bennett's Principles and Practice of Infectious Diseases. 7th ed. Philadelphia: Elsevier Churchill Living-stone; 2009, pp 3613-3615.

7. Lam KS, Faraj A, Mulholland RC, et al. Medical decompression of vertebral hydatidosis. Spine 1997;22:2050-2055.

8. Bhojraj SK, Shetty NR. Primary hydatid disease of the spine: an unusual cause of progressive paraplegia. J Neurosurg 1999:91;216-218.
9. Santavirta S, Valtonen M, Patiala H, et al. Disseminated hydatid disease causing paraplegia and destruction of the hip. Arch Orthop Trauma Surg 2000:120;118-120.

10. Kuremu RT, Khwa-Otsyula BO, Svanvik J, et al. Hydatid disease of the spine: case report. East Afr Med J 2002:79;165-166.

11. Ranganadham P, Dinakar I, Sundaram C, et al. Posterior mediastinal paravertebral hydatid cyst presenting as spinal compression: A case report. Clin Neurol Neurosurg 1990:92;149-151.

12. Pabuşçu $Y$, Taşar $M$, Gezen $F$, et al. Spinal korda bası yapan paravertebral hidatik kist. GATA Bülteni 1995;37:357-360

13. Bhojraj SY, Shetty NR. Primary hydatid disease of the spine: an unusual cause of progressive paraplegia. Case report and review of the literature. J Neurosurg 1999;91:216-218.

14. Awasthy N, Chand K. Primary hydatid disease of the spine: An unusual case. Br J Neurosurg 2005;19:425427.

15. Kahilogulları G, Tuna H, Aydin Z, et al. Primary intradural extramedullary hydatid cyst. Am J Med Sci 2005;329:202-204.

16. Takayanagui OM, Bonato PS, Dreossi SA, et al. Enantioselective distribution of albendazole metabolites in cerebrospinal fluid of patients with neurocysticercosis. Br J Clin Pharmacol 2002;54:125-130.

17. García-Vicufla R, Carvajal I, Ortiz-García A, et al. Primary solitary Echinococcosis in cervical spine. Postsurgical successful outcome after long-term albendazole treatment. Spine 2000;25:520-523. 